\title{
SAROYAN'S FILIPINOS
}

\section{Undoing Invisibility and Silence in Subaltern Spaces}

\author{
Mauricio D. Aguilera Linde \\ University of Granada \\ aguilera@ugr.es
}

\begin{abstract}
Before John Fante's stories about Filipinos and Carlos Bulosan's autobiography were published, William Saroyan's depiction of Filipino migrant workers provided one of the earliest representations of a minority doomed to invisibility and silence during the 1930s and 1940s. This article offers a careful reading of the Filipino's presence in his fiction through an analysis of the narratorial techniques deployed and the symbolism of the characters in two of his stories, "Our Little Brown Brothers the Filipinos" (1936) and "1924 Cadillac for Sale" (1938). In the first, by resorting to the tradition of the tall tale in a boxing story, the author disavows the raconteur's ideology of racism and the hegemonic belief in the Great White Hope. Ramon's victory signals the suspension of the alleged inferiority of the "brown savages" and becomes the stand-in justification for the long-overdue vindication of his people. Simultaneously, by allowing the Filipino farmhand to fix the jalopy in the second title, Saroyan manages to resurrect the pastoral ideal of America, thereby reviving the belief that marginalized immigrants, and not machines, can still be the driving force of the nation weathering an economic crisis.
\end{abstract}

\section{Keywords}

Saroyan's fiction; Filipinos in the great depression; counter-hegemonic strategies of ethnic representation; boxing literature; ghetto pastoral

\section{About the Author}

Mauricio D. Aguilera Linde is a Senior Lecturer at the University of Granada, Spain. A visiting senior fellow at Rutgers University (US), University of Delhi, Utkal University, University of California at Berkeley, and a visiting scholar at Stanford University on several occasions, he has been actively involved in the research of contemporary American drama and short fiction. His current research interests are centered upon diaspora and memory, more specifically the immigration stories of the Great Depression and the disjunctions of memory frames. He has 
written a number of articles on Saroyan's theater and short fiction in journals such as American Drama (University of Ohio) and Zeitschrift für Anglistik und Amerikanistik (De Gruyter), among others, as well as several chapters on the intertextual references of Saroyan's short fiction on Álvaro Cepeda Samudio's work. His Spanish translation of Fakir Mohan Senapatis's masterpiece Six Acres and a Half was awarded the 2018 Fakir Mohan Saraswati Samman. 


\section{INTRODUCTION}

“Saroyan's work appealed to me because he was one California writer who never lost sight of the darkness."

(Richard Rodriguez, "Interview with Gerald Haslam"

[San Francisco in Fiction: Essays in a Regional Literature], 122)

"Gorki made me aware of his counterparts in America: Jack London, Mark Twain, and the youngest of them all - William Saroyan."

(Carlos Bulosan, America is in the Heart, 246)

When William Saroyan wrote the preface to Three Worlds (Hairenik, 1939), the first anthology containing stories by Armenians of the Old World, Armenians born in the US and the third generation of young Armenian-American writers, he did not hesitate to admit that only a "healthy racial consciousness" ${ }^{1}(\mathrm{xv})$ could contribute to bringing "fresher cultural values" (xvi) that would help to rejuvenate the nation and finally put an end to the embarrassment that the foreign-American feels "about his difference from older tribes of Americans" (xv). In laying bare the necessity of the ethnic element as the driving force of the cultural pluralism that must nurture the new American, Saroyan was clearly anticipating the principles that Louis Adamic would state later in 1940 when he set out to publish Common Ground, the journal that set out to demonstrate, among other things, that Americanism was by no means "the monopoly of any group, let alone the White Anglo-Saxon group," and that a nation free of "intolerance and discrimination," by principle had to "uphold the freedom to be [racially and culturally] different" (70). Rather than assimilation, the reductio ad unum of the diversity of peoples arriving on the continent, the goal was to avoid the imperative of a monocultural paradigm in the making of the nation.

Saroyan's attitude towards ethnicity is not exempt from contradictions. Whereas he adopts a pan-ethnic position based upon the principle of Paulinist fraternity among all races-"An Armenian is a Turk who says I am an Armenian. It is a decision open to all people" condenses the author's belief that mankind should go beyond the boundaries of racial differences ("Haratch" 153) - his fiction is, however, obsessively devoted to the careful depiction of the peculiarities (and deviations from the norm) of immigrants. In a 1941 essay, John Fante defines Saroyan's writing as deeply marked by his ethnic identity, scorned and despised by white Americans, the source of an unhappy childhood that becomes the theme of his nine books: "It is grudge-writing ... the little Armenian-American boy shrieking, singing, laughing, somersaulting, demanding to be heard" (64). "You can't move out of your 
heritage, but you can move out of your environment" was Saroyan's answer to Sean O'Faoilan's question: "Do you ever feel more Armenian than American?" (Stanford 28). ${ }^{2}$

In what follows, I aim to analyze Saroyan's contribution to the question of ethnic debate by focusing my attention neither on his central protagonists, Armenians living in Little Armenia, Fresno, nor on any of the endless groups of immigrants that can be found in his fiction: Jews, Italians, Yugoslavs, Greeks, Syrians, Mexicans, Russians, Poles, and a long etcetera. My intention is to put the spotlight on a minority that embodied, for a number of complex historical reasons, a different immigration paradigm: Filipinos. As E. San Juan, Jr. argues, between the defeat of the Aguinaldo Republic in 1901 and the establishment of the Philippine Commonwealth in 1935, Filipinos were, strictly speaking, "not immigrants but exiles, deracinated subjects, displaced colonials, sojourners not settlers" ("Internationalizing" 131). After 1935 they became "full-fledged aliens and were subject to repatriation and deportation" (132). Colleen Lye holds that the representation of the Asiatic racial form was never given a full ontological subjectivity until the publication of Pearl S. Buck's and John Steinbeck's work. Rather than distinct individuals with their differences and problems, they were always treated as members of a collectivity (55). Saroyan's Filipinos are, however, represented as full-fledged individuals with strong rebellious spirits who refuse to obey and conform. My contention is that the appearance of the Filipinos in Saroyan's short fiction underscores not so much the deterritorialized Filipinos' subaltern nature as their subversive, usurpationary potential to fight against oppression, and their almost innate ability to restore the principle of diversity. William Boelhower contends that "an ethnic sign is only ethnic if it is produced or interpreted as such by an intending subject" (38). Quite unlike Henry James's encounter with the Italian ditch workers and his inability to communicate with them, resulting in dumbfounding silence, that Boelhower so brilliantly analyzes in Through a Glass Darkly: Ethnic Semiosis in American Literature (1987), Saroyan's gaze of the Filipinos reveals that the dispossessed and the despised may hold the key to expanding the limits of liberty and rewriting the primeval myth of the American nation. In one way, Filipinos become the embodiment of a force which triumphs in the face of adversity and disadvantage and which proves to be instrumental in revitalizing the genuine spirit of the American nation.

Saroyan's preoccupation with ethnicity does not only contest the supremacy of the white epistemic gaze, as his major critics (Edward Halsey Foster, Stephen Calonne and Nona Balakian, among others) have noted, at a time dominated by immigration, exclusion and discrimination. It also disrupts the pedagogy of the national discourse by calling concerted attention to national (in the case of the Filipino, stateless) "others" and their subjugated histories. Walter Shear (1986) has analyzed Saroyan's most celebrated book, My Name is Aram (1940), as the emotional

Kritika Kultura 35 (2020): 98-117

(C) Ateneo de Manila University

<http://journals.ateneo.edu/ojs/kk/> 
record of the Armenian experience in California at the dawn of the twentieth century. Aram, the loquacious wiggler, becomes the go-between of the hegemonic world with its limiting rules and rigid regulations imposing assimilation, distance and forgetting, and punishing those whose behavior impinges on the norm, and the ethnic community struggling to articulate, and remember, other marginal values which guarantee the survival of their own (sub)culture. Thus, the Armenians of Fresno portrayed by Saroyan, as Calonne puts it, "celebrate the triumph of freedom [of the spirit], of the intense over the quotidian" (64): they defy logic, remain silent and distrust words; encourage knowledge from books but mostly favor the wisdom provided by experience; give priority to beauty and pleasure, and, unlike their moneydriven, work-frazzled American fellow citizens, show a nonchalant attitude towards success, personality, and material profits. As if in anticipation of Homi K. Bhabha's ideas, Armenians unwittingly disturb the homogeneity of the imagined community of the host nation since they resist integration. "The Armenian was not eager to forfeit his culture in favor of the American culture. The fact that he couldn't do so, even if he had wanted, is perhaps beside the point," adds Saroyan in The Bicycle Rider in Beverley Hills (56).

In reading Saroyan's Filipinos, I do not simply intend to reassess the importance of the ethnic element in the stories as the locus of dissidence against an imperialistic agenda that pursued the suppression of "other" national narratives, an ideological starting point that has never been sufficiently acknowledged in the writer's short fiction and theatre. My goal is also to examine how the author deploys a series of narrative strategies (boxing literature, tall tales, and the ghetto pastoral) that encapsulate subversiveness in the guise of seemingly naturalistic stories defined by simplicity and humor. As Michael Denning has rightly observed, "realism as a social convention ... is tied historically to social power: a group must have a sense of agency in order to imagine realistic stories about themselves. The powerless ... have characteristically chosen allegory" (249). Without this allegorical thrust in mind, the Saroyan stories can only read as the apolitical, banal anecdotes of an author who "knows so little and gives himself so little to think about" (Christina Stead, qtd. in Foster 31). ${ }^{3}$

Although Saroyan's importance as an enduring source of influence for AsianAmerican writers (Carlos Bulosan, Jose Garcia Villa, Toshio Mori, and Charles Kikuchi, among others) has long been acknowledged (San Juan 2019; Matsumoto 2014; Briones 2012), no critical attention has been paid to the ways his ethnic fiction celebrating the minorities' conflicting identity and, more specifically, the narrative strategies employed for that goal, may have nurtured first-and-second-generation immigrant writers' imaginations. In the subsequent sections, a brief outline of the history of the Filipino workers in the US - the so-called manongs-will be included with a view to understanding the historical backdrop against which the stories

Kritika Kultura 35 (2020): 99-117

(C) Ateneo de Manila University

<http://journals.ateneo.edu/ojs/kk/> 
must be interpreted. It is not my intention to provide a catalogue raisonné of the Saroyan texts where Filipinos occupy center stage or play a significant role. It is also beyond the scope of this article to deal with a frequently anthologized story like "The Filipino and the Drunkard."

\section{FILIPINOS IN CALIFORNIA}

"The days of hunger and loneliness came. Aching hunger and stifling loneliness. Every dawn was the opening of a cavern of starvation and exile. ... 'You must be strong in America,' said my brother to me."

(Bulosan, America is in the Heart 137)

Pinoy workers who arrived on the West Coast and Hawaii were regarded, in San Juan's words, as "nomadic subaltern[s] without citizenship rights, almost ... refugee[s]" "Internationalizing" 131). Filipinos went through a number of statuses between the US colonial annexation in 1898, a decisive part of the westward expansion to the Pacific as the gateway to marketplaces in Asia, and the declaration of independence of the country in 1946: from colonial subjects, incapable of self-rule, under the policies of President McKinley's benevolent assimilation; to "protected wards" without citizenship rights under the tutelage of the US (after the 1916 Jones Act); and eventually, with the passing of the Tydings-McDuffie Act in 1934, becoming illegal subjects who could be lynched, arrested and deported. Along with the Japanese immigration problem, Filipinos represented, in the words of the chair of the California Joint Immigration Commission, "the worst form of Orientals" (Lee and Yung 280). Yen Le Espiritu (2003) suggests that Filipinos alone embody a paradigm that she calls "differential inclusion" (47) rather than "outright exclusion," a process by means of which they were included because they were regarded as valuable for the nation's economy, culture and power. However, to be included, they had to be "rendered homeless," i.e. deprived of any legal rights, economically exploited and culturally degraded. Thus, they were "coercively and differentially made to be part of the nation" (48). In Lye's view, Asians became "a disempowered class of laborers," "different from, if overlapping with, chattel slavery" (20). The number of prohibitions Filipinos were subject to in California during these years are summarized in a list of ten general points in Carlos Bulosan's autobiography:

“How come we Filipinos in California can't buy or lease real estate?” a man asked.

"Why can't we marry women of the Caucasian race? And why are we not allowed to marry in this state?"

Kritika Kultura 35 (2020): 100-117

(C) Ateneo de Manila University

<http://journals.ateneo.edu/ojs/kk/> 
"Why can't we practice law?"

"Why are we denied the right of becoming naturalized American citizens?"

"Why are we discriminated against in relief agencies?"

"Why are we denied better housing conditions?"

"Why can't we stop the police from handling us like criminals?"

"Why are we denied recreational facilities in public parks and other such places?"

(Bulosan 269)

Suffering demonization, ostracism, discrimination, and the privation of their basic human rights, Pinoy workers were abused and exploited by "labor contractors, farmers, gamblers, racist vigilantes, and by state laws" (History and Form 62), thereby epitomizing the transition from colonial subordination to "neocolonial marginality" ("Internationalizing" 130). Being non-white, Filipinos were inevitably reduced to silence. David Theo Goldberg explains that the racial others are seen as "incapable of speech and in the end of being spoken about" (92). Silence produces invisibility: non-whites must be placed outside time and outside "the spaces of modern time" (93). As Oscar Campomanes has shown, Filipinos articulate a "de facto invisibility", an "incommensurable sense of nonbeing" (50) since they represent the "self-effacements of empire," "the New Empire's forgetful and forgotten citizens" (178). Not in vain, they must be pushed to those places unreached by civilization: no matter where they travel, "Filipinos will take the jungle with them" (qtd. in Le Espiritu 57). Saroyan's stories can be read as one of the earliest attempts to counteract the strategies of silence and invisibility advocated by the hegemonic apparatuses of the state. Set against this ideological backdrop aiming at a systematic effacement of the Filipino presence, his tales can be analyzed as sites of contest against the immigration policies enforced by the US at one of the most critical times of American history.

\section{SAROYAN'S “OUR LITTLE BROWN BROTHERS THE FILIPINOS”}

Included in the seventh section ("The Japanese are Coming") of his voluminous second collection of short fiction, Inhale and Exhale (1936), "Our Little Brown Brothers the Filipinos" exemplifies the type of story in which Philip Rahv believed that the writer was at his best: "He is more successful where he manages to discard the poetry of the ego and eternity in favor of a more objective field of reference ... The less there is of Saroyan as a subject," the better his stories are ("Narcissus" 84). The story's title, a reference to the expression coined by the American Governor of the Philippines and the 27th President of the US, William Howard Taft, denotes a paternalistic racism that justifies McKinley's doctrine of "benevolent assimilation," one which averts the violence of the conquest by presenting colonial rule as 
the most precious gift that can be bequeathed to undeveloped "people without history" (Wolf). The irony comes immediately in the opening line of the narrator's introduction: "I don't suppose you ever saw a two-hundred-a-fifty-pound Filipino. They don't come that size very often, but when they do, brother, look out. It's as bad as an earthquake or a hurricane" (Inhale 325).

The piece can be classified as an example of boxing literature, one of the staples of dime novels during the 1920 s and 1930s, the kind of story that Ben Hecht popularized at the time. Michael Denning sees boxing literature, along with Horatio Alger's tales, detective stories, and pulp fiction, as one of the models that attracted working-class American writers and haunted the so-called ghetto-pastoral: low, degraded outlaws living in the slum, an enclave defined by ethnicity and race (244-246). The tale concerns a heavyweight wrestler, Ramon Internationale, who stubbornly refuses to abide by the rules of a framed match and remains in the ring all night, until he is declared the winner, fighting his opponent, his manager, the timekeepers, the referee and half of San Francisco's police force, two hundred men equipped with "sawed-off shotguns, tear-gas bombs, clubs and horses" (Inhale 329). The story itself-Ramon's resistance to letting himself be defeated-is narrated by Tom, who is addressing a newcomer who has never heard of the Filipino pugilist and the huge commotion he aroused in the city when "people from all over San Francisco" (Inhale 330), "every man, woman and child" (Inhale 331) rushed to the boxing stadium, filling it up, while "a crowd of three thousand people in the streets" remained outside waiting and booing. The frame story device-the dialogue that Tom holds with someone who shares neither knowledge of the city nor the rules of prizefighting - and the number of exaggerations and incongruities with which the inflated story is interspersed, are reminiscent of the tall tale tradition. Tom is the white male yarn spinner and the addressee is the greenhorn who remains mostly silent, except to state that he has never heard of Ramon or read about the incidents in the newspaper, probably wavering in his acceptance of the story's credibility. Faithful to his role as tall-tale narrator, Tom, however, puts in every effort to demonstrate that his testimony can be nothing but true. Not only is he an eyewitness of Ramon's unbridled, animal-like strength, capable of putting "the ligaments of [his] left leg in a knot" (Inhale 325) and throwing Vasili Ivanovitch, the Russian opponent, the referee and the reporters out of the ring several times, but also compares the Filipino's unparalleled brawniness with the most famous heavyweight champions of the times, namely Jimmy London, Strangler Lewis, Jack Dempsey, and Firpo, the Argentinian bull of the Pampas: "Well, this baby was all of those guys in one large package" (Inhale 325).

Carol S. Brown's analysis of the tall tale formula (1987) might help us to isolate some of the features that can be traced back in Saroyan's story: (i) The outlandish plot (the comic lie, hoax, or exaggeration) that creates a "hazy border between 
the credible and the incredible" (38); (ii) the suspension, mockery or challenge of what has been traditionally believed or held to be true, thereby destabilizing the natural order or "doing away with a little bit of the threat of a disorganized universe" (37); and (iii) the acceptance that the world is an amoral space where "survival and humor are far more important than ethics” (38). Brown resorts to Roger Abraham's concept of "deep cultural matrix" (31), i.e., the specialized knowledge that is an integral part of the group's common experience, to explain how the joke can only be properly decoded by the members of the in-group that are capable of seeing through the intricacies of the verbal trickeries and grasping the gist of the comic story. Henry B. Wonham (1993) also uses this concept of "deep cultural matrix" to comprehend the communication act underlying the pragmatics of a tall tale: only those listeners "competent to receive in the spirit of fiction a narrative that is told as a fact" (23) can take the fantastic yarn without feeling taken in and enjoy the narrator's non-stop stretching of the limits of credibility. However, the tall tale occupies "a rhetorical middle ground" (35): it is neither entirely true nor blatantly false but stands somewhere between fact and fantasy. Rejecting the story's truth claims or else accepting them at face value show that the listener has been unable to grasp the story or entirely misinterpreted its meaning. Tall tales, Wonham remarks, "contain more than one potential meaning-[they do simultaneously] express a will to tell a lie and a contradictory will to tell the truth" (31). Before delving into the core of this narrative about Ramon Internationale, we must endeavor to understand the complexities of the "deep cultural matrix" which underlies the world of prizefighters during the 1930 and, more specifically, the story behind Filipino boxers during the Great Depression, if our aim is to become "cultural insiders" who can see how the narrator's yarn hides a truth under the masquerade of an impossible exaggeration. 


\section{FILIPINOS IN THE RING}

"Years of degradation came into the Filipino's face. All the fears of his life were here-in the white hand against his face."

(Bulosan, America is in the Heart 145)

"The survival and triumph of the despised has got to give God a roar of laughter."

(Saroyan, Short Drive, Sweet Chariot 116)

During the 1920 and 1930 , Filipinos became the most prominent prizefighters in the US. Joel Franks's engaging monograph entitled Crossing Sidelines, Crossing Cultures: Sport and Asian Pacific American Cultural Citizenship (2010) provides a thorough historical account of the most important boxers who arrived in California under the patronage of Filipinos living in Los Angeles, San Jose, and San Francisco. Names such as Pancho Villa (Francisco Guilledo), nicknamed as the Little Brown Champion and dead at the age of 24 from a tooth abscess, Klino Flores, Ceferino Garcia (a.k.a. the Bolo Puncher, a tactic he learned while cutting sugar canes in the Philippines), Speedy Dado, Small Montana, Young Tommy and a long etcetera became flamboyant heroes who attracted thousands of Pinoys who traveled hundreds of miles to see them live and cheer them on.

Boxing was not only a form of mass culture entertainment "with elaborate cults of personality" (Vials 7) and a sophisticated display of "corporate control, commercial sponsorship, mass-mediated publicity and mass spectatorship" (Streible 11). Boxing, as Chris Vials contends, was also "a racialized spectacle arousing hopes among either blacks or Filipinos" of climbing the social ladder, "[a] poor boy's ticket out of the obscurity and into the world," in Nestor Enriquez's words (qtd. in Franks 32). Furthermore, the ring was soon regarded as a platform where manly virtues such as physical strength and self-control could be cultivated in an attempt to halt the growing feminization of the American nation, and "an instrument to protect the [white] race against inferior immigrant strains" (Streible 11). If the prizefighter was black or brown, the fight was viewed as a contest between races to prove his superiority. The primitive brute's physical strength could by no means dominate the superior strategy of the white man's brain. Defeating the "racialized other" in the arena was "akin to a public lynching for blacks who did not know their place in American society" (Sammons 35). The Great White Hope, a white pugilist outclassing a racial opponent, was the only way to put an end to spurious claims for an egalitarian society. 
There are three much-talked-about fights that caused riots, broken chairs, and noisy protests against crooked fights in favor of white boxers and that might well have inspired Saroyan's outlandish tale of Ramon's stoic defense of his vital need to be declared the winner against the law and order of San Francisco:

1. Ceferino Garcia, a symbol of "the primitiveness and 'cheap labor' of colonial natives" (Franks 33) was defeated by Italian-American Young Corbett in Los Angeles in May 1932, with the referee's decision provoking several hundred Filipinos to voice their discontent, "claiming racial discrimination" (Franks 38).

2. A similar reaction on the part of the Filipino community can be found in the Speedy Dado vs. Midget Wolgast fight in Oakland in September 1932, which ended in a draw. Filipinos distributed thousands of handbills in the San Joaquin Valley region denouncing crooked fights and discriminatory ticket-selling policies (they could only buy the most expensive seats), and threatening to boycott the bout (Franks 38).

3. Henry Armstrong's 1933 victory over Kid Moro in Pismo Beach, California, a decision Filipinos saw as the result of another framed fight, ended up in a tumultuous riot (Franks 39).

Saroyan's story provides a vivid description of the thousands of die-hard Filipino fans who had bet money on Internationale and who never tired of cheering their countryman, not one of them "more than hundred ten pounds in weight, but every one dressed in purple and red and green clothes, every one smoking a long panatela cigar" (Inhale 327). Their resistance to abandoning the auditorium until Ramon is officially declared the winner and their strategy to defend themselves from being run out by the police horses by throwing soda bottles and locking themselves out in the balcony section run parallel to the pugilist's steadfast decision "to stand alone in the center of the ring" atop a horse, defying the police, the law, and the whole city of San Francisco (Inhale 238). Ramon's self-willed insistence upon not leaving the ring and his seemingly cryptic refrain "You know nothing," repeated throughout the story, to his manager on several occasions and in the speech to the audience, gain a deeper significance within this context:

Ladies and gentlemen, you know nothing; you do not know anything. The referee says I am the loser of this match, but you know nothing. I am the winner. I challenge Vasili Ivanovitch, the Russian rock crusher, to return to this ring, and I challenge anybody else in this audience to enter this ring, and I will not leave this ring until the referee declares I am the winner. (Inhale 328)

Kritika Kultura 35 (2020): 105-117

(C) Ateneo de Manila University

<http://journals.ateneo.edu/ojs/kk/> 
The fight is no longer against Vasili Ivanovich but against the alleged inferiority of Filipinos, their history of abuse and exploitation discussed above, the fact that, as Bulosan puts it, "their lives were cheaper than those of dogs" and they were "forcibly shoved off the streets when they showed resistance" (142). Being declared the winner is paramount to reasserting the dignity and pride of one's race and rebelling against the status quo. "People love to see one man, especially someone dark-complected, challenging the world" (Inhale 330) is Tom's tongue-in-cheek conclusion of a tale that can only be understood if we are able to grasp its truth and its lie simultaneously. The tale's distortion of plausibility is reinforced by the fact that Ramon's victory takes place in an auditorium that becomes the locus of a wild fantasy, a place that is appropriately called Dreamland. Filipinos were unable to debunk the dynamics of white supremacy during the 1930s. What is true about the old-timer's yarn is what Ramon conceals behind his haunting "You know nothing." The gorilla-like fighter, a manong brought from the pea fields in Salinas by his manager, embodies decades of colonial dispossession and neocolonial marginality. His challenge of the agreed-upon rules of the framed bout becomes the gravitational center of a counter order that jeopardizes the police surveillance and legal system represented by the municipal authorities. Ramon's disavowal of the Great White Hope is, the chief of the police chimes in, "worse than a strike ... ten times worse" (Inhale 332).

Not in vain does the raconteur's construction of the colonial dark other reinforce the "phenomenon of reciprocity" that Campomanes has observed in racist discourses: the past representations of blacks and Native Americans reappear and coalesce in the figure of the Filipino brown savage. Ramon, "the biggest and toughest and wildest gorilla that ever got out of the jungle in to the world" (Inhale 325 ), is closer to the monkey than to man. His infantile primitivism can also be detected in his proximity to the other animal he accepts in the ring, the horse. As to the rest of the Filipinos, the only aspect highlighted by both the narrator and the chief of police is their stylish dress ("What the hell are the well-dressed Filipinos doing here?" [Inhale 330]), a white middle-class identity sign that working-class Filipinos appropriated after their arrival in America (España-Maram 116-117) and to which I will return later on in my analysis of the next story.

The crux of the tale is whether Tom's flights of exaggeration about Ramon's feat of endurance (a wonder like the "birth of the quintuplets" [Inhale 330]), capable of putting against the ropes the police's coercive force and even the mayor's authority, is a discourse that revalidates a racist standpoint in relation to Filipinos. Wonham points out that the literary tall tale, unlike its oral counterpart, does not unify and redeem the identity of a yarn-spinning community. Now disagreement rather than unanimity prevails, and the old-timer's tale is no longer the locus where communal values are reinscribed. If the deep cultural matrix of the readers of the time is one 
defined by stereotypes against Pinoys, Saroyan's story disavows the elite group's racial myth by enticing readers into taking sides with Ramon's plea. His refusal to cooperate ("Why do I have to lay down for them?" [Inhale 327]) becomes the fault line through which the reader begins to resurrect the subjugated knowledge of the oppressed minority. As Balakian rightly observes, beyond the absurdities of the story, "what stays with the reader is the spectacle of sweet victory" for the powerless and disadvantaged (104). The white boundaries have been at least temporarily transgressed. In tune with what C.L.R. James argues about the racialism of cricket in the West Indies, Ramon's victory is not the triumph of a single individual pitted against another. It galvanizes the belief for the rest of the Filipinos that it is possible to win against white rule and be free from racist constraints.

\section{SAROYAN'S “1924 CADILLAC FOR SALE”}

“That's because you know most folks can't afford to own one of these Caddies. Not even good, hard-working folks, no matter what the pictures in the papers and magazines say. So deep down it makes you feel larceny. ... life is hard and earnest and these here Caddies is way, way out of this world!"

(Ralph Ellison, "Cadillac Flambé" 446).

Saroyan's third story in which Filipinos play a significant role, "1924. Cadillac for Sale," was originally published in Hairenik Weekly on September 2, 1938, and later included in his 1939 collection, Peace, It's Wonderful. The story uses first-person narration. A peculiar dealer of second-hand cars, most of them jalopies he feels it morally reprehensible to sell for they are rusty pieces of junk unable to be driven again, tells us of the change in buying habits he has been observing in his new clientele which, surprisingly, now prefer to purchase used cars. Whereas in the past he had to employ every skill of persuasion to sell the "out-of-date broken-down heaps" (Peace 156) to potential buyers, now, with the crisis severely affecting the country, business goes smoothly: "I used to sell an average of two used cars a week five years ago but nowadays I'm lucky if I don't feel two a day" (Peace 156). There is no need for him to insist on the truth about the old heap they are getting or to give them any rehearsed spiel about its (lack of) virtues- "I ain't selling anybody anything. I'm just letting the tide of humanity rush where it pleases":

An old lady who doesn't know how to drive a car wants to buy an old Hupmobile because it's green, so why should I interfere with her wishes? ... She buys it anyway, and the next day I see her going down the street forty-three miles an hour. She is in sports

Kritika Kultura 35 (2020): 107-117

(C) Ateneo de Manila University

<http://journals.ateneo.edu/ojs/kk/> 
clothes, and the radio's going full blast, with a crooner hollering "Deep in the heart of me." (Peace 156)

The salesman's attention is centered on a new customer, a young Filipino called Vernon Roxas, a farmhand who has been working in Bakersfield and managed to save up some money. His intention is to buy a Packard sports roadster, a model dating back to 1908 that the car dealer uses as a decoy in his shop for he knows that there is some unrepairable problem with the engine. The car was abandoned in the desert and there is no way to put it back on the road again. Although he tries hard to advise him against buying it, Vernon is adamant that this, and not any other, is the right automobile for him.

William Boelhower $(1989,160)$ argues that modernism, the new cultural episteme with its obsessive literary experimentation based upon fragmentation, juxtaposition and collage, reminiscent of the traffic-congested, machine-dominated metropolis, was unable to solve the conflict posed by the crisis of the Great Depression. The strategy used by ethnic writers to overcome this cul-de-sac was to recover the subject's agency and to redefine reality as a historical construct. Boelhower observes that only a genealogical project (our fathers' dream of a Promised Land) can restore the meaning of a world perceived as lacking any coherent principle and stability. Saroyan's experimental modernism, however, oscillates between his failing to endow his ethnic background with a solid genealogical narrative and his resistance to sublate his immigrant experience into the universal language of modernism. Interestingly, this permanently unsolved contradiction was noted by Philip Rahv's well-known review of Saroyan's first book when he inveighed against the Armenian-American writer's fear of "objective life" and his retreat into "the seductive mysteries of the dreams and stasis" (84). Saroyan's stories are therefore caught up in the dilemma of portraying the harsh living conditions of "Fresno niggers" 5 or to escape into a pastoral dream of a land untouched by the contingencies of history. It is this juxtaposition of irreconcilable principles that defines his narratorial project, one which hovers between the naturalistic impulse to portray slum life in the wake of the 1929 crisis and the need to carve out a space where the pastoral ideal of freedom and equality of races can be recreated. ${ }^{6}$

The machine occupies a central position in Saroyan's short fiction. In a nutshell, it represents the forces working against, or at least postponing, the dream of pastoral fulfillment. Leo Marx's classic study The Machine in the Garden (1964) provides a seminal account of the perpetual conflict between the industrial progress and mechanization of the nation's life and the deeply rooted conviction that America was the virginal land where man could live in perfect harmony with Nature. The dissonance between these two forces, the rural myth and the technological fact, occupies, as Leo Marx explains, a prominent place in the early twentieth century, 
the wrangling animosity between them reaching its climax during the Great Depression. One of Walker Evans's most emblematic photographs of the Great Depression is "Joe's Auto Graveyard" (1936), a snapshot taken near Bethlehem, Pennsylvania, in November 1935, showing a jumbled collection of junked cars abandoned in the countryside, slowly being buried by the grass and silently being watched by the trees in the background; "a herd of disabled animals" that huddle together (Mellow 277); a mechanical pastoral landscape in short that can be read not so much as a critique of the wastefulness brought about by mass production but as a complex symbol of "the entangled and contradictory energies that drive American culture" (277): Techne vs. Nature. We find an identical tug of war of these forces in Saroyan's early short fiction. His story "Panorama Unmerciful" (1936) revalidates the bitter belief that the dream of progress cannot be made compatible with our true identity: "The earth is good and living is good, only that they have gotten us into such a mess with their arrangement that we forget to focus our vision on the splendid things and we lose track of our proper function here ... I wonder why we cannot be more of the earth and less of the false things we have made and that are destroying us" (Inhale 242). Saroyan sees man's existential dilemma as one being trapped by the fear to "pause and look around and know that everything [he has] made so far has proved futile" (Inhale 242). We live in a machine age: "The wheel and the piston and the iron finger, the million iron fingers, the million iron minds, the heartless bloodless living steel and the mirage of twirling tons ... Do we fear machinery? ... Why do we speak so often of junk?" ("The Great Unwritten American Novel," Inhale 253).

If the 1929 crisis entails the suspension of the belief in the power of the machine to redeem mankind, there is no other solution than to return to nature. This is the conclusion reached by the child narrator of "Yea and Amen" (1936). The children visit the cemetery of objects, the ill-assorted collection of rusty things that are brought together in the city's junkyard: "broken-down wagons, old automobiles, Dorts, Saxons, Moons, Jordans, beds, bed springs, piles of pipes, bottles, implements" (Inhale 174). Things made by man decay, they are simply "the designs with which [we have] graced the void ... the emptiness" and in due time, with their passing, confirm that "God [is] perishing in ugliness and imperfection" (Inhale 174). Only the discovery of an egg just laid by a stranded hen they have just rescued from the street can eventually restore the faith in life: "this oval of whiteness could never end, and out of its shape and meaning all the shapes of man could be abundantly increased" (Inhale 177).

A similar lesson is learned in "Raisins," a story about man's hope to turn a farming town in the desert into a beacon of progress and industrialization. The Jeffersonian ideal of rural peace comes to a halt when a newcomer, an educated man who "wore spectacles" and "looked important" (Inhale 159) brings an idea into 
the townspeople's mind. If they make American people and the rest of the world accustomed to eating raisins on a daily basis they can become "one of the richest agricultural centers of the world" (Inhale 160). All they need is a system of mass production along with an investment in advertising that might create a demand for raisins nationwide. A factory is then erected, a six-story building with a huge packing and distributing plan. However, the dream of progress is soon shattered. People stop eating raisins because they are a luxury. In no time the factory is closed down, the machinery turning into junk and the packing house becoming "a useless ornament in the landscape" (Inhale 163). Only the truth of the desert, with its "strong dry weeds" and ubiquitous "jackrabbits," remains.

Yet, despite Saroyan's mistrust of technology, “1924 Cadillac for Sale” opens up the possibility not only of bringing the machine back to life, with its metaphorical implications within the context of the crisis, but also of restoring the human ability to lead the way, overcome obstacles and move forward. As the narrator remarks, it's not the machine but "the awful energy of the people" that can instill new life into the "worthless heap of junk" (Peace 158). What is relevant here is that the narrator chooses Filipinos as the performers of this miracle. The subaltern takes on an agentive role. After selling the old Packard to Vernon, the manong comes back with a group of eleven well-dressed Filipinos who start working on the automobile until it "slowly drove out of the lot with the motor barely making any sound at all, like the motor of a car just out of the factory" (Peace 158). The car dealer stands "with the mouth open" before the Filipinos' "beautiful cooperation and strategy" (Peace 158), their faith in themselves before "an exhausted piece of machinery," their "superb adaptability" to harsh living conditions (Peace 157) "in the best style of clothes," their "impressive" American first names (Thorpe, Scott, Avery, "them ain't names you ever see attached to people, native or alien" [Peace 157]), and finally, their "polite impudence to want class" (Packards and Cadillacs are brands purchased by the elite $)^{7}$ despite their humble social origins. "I felt awfully proud of them young citizens" (Peace 157). Not only are they "sensible, honest and sincere" (Peace 157) but they belong to a "great race of adventure-loving people who can't be stopped by truth or expense" (Peace 159). The Filipinos' fight for a cause that may seem initially lost demonstrates their ability to move beyond material constraints in a mechanistic, machine-dominated age: "they'd fought a battle and won" (Peace 158). In short, the marginalized Pinoys can resurrect the dream of America.

\section{“ACROSS THE BOARD ON TOMORROW MORNING" (1942)}

Premiered in Pasadena Playhouse in 1941 and presented in a double-bill program one year later in the Belasco Theater, New York, on August 17, 1942, "Across the 
Board on Tomorrow Morning” is one of Saroyan's plays full of long speeches interspersed with non-sequiturs that Nona Balakian sees as "a foil for philosophical meditation" and a springboard for theatrical experimentation that foreshadows the theater of the absurd (256). Conceived as a barroom play, partly stemming from his Pulitzer-winning play, "The Time of Your Life" (1939), its dramatis personae are, among others: Thomas Piper, a waiter who acts as a narrator directly addressing the audience in a presentational style; Harry Mallory, a philosophical man who reflects on "the configuration of error and crime which is called contemporary history" (121); R. J. Pinkerton, an elderly man from Wall Street; Rhinelander 2-8182, a woman who delivers a baby; and two Filipino kitchen boys, Pablo and Pancho, whom George Jean Nathan sees engaged in a dialogue that, "if properly directed, would constitute tip-top humor" (41). In two scathing reviews of the play, Eugene Burr analyzes the one-act play as the creation of "an egomaniacal incompetent" ("New Play on Broadway" 10) interested in tormenting his audience with "some stupid horseplay and a succession of interminable stupid speeches" ("Across the Board" 10). Burr's summary of the plot lines reveals how useless trying to detect a cause-and-effect sequence of events in a play that is not intended to be realistic proves to be: a waiter talks to the audience "endlessly and pointlessly"; the bar proprietor offers a dancing number; a young man changes coats with the waiter; when the end of the world seems to be approaching, a baby is born but in no time he walks in, in the guise of a young man; at a certain point in time before the baby's birth:

two Filipino dishwashers come in and insult an elderly man because he doesn't know the statistics connected with the Philippines, and then force the young lady ... to stand up so that they can judge the aesthetic effect of her rear elevation. ("New Play on Broadway" 10)

The play must be read as an allegory of the world on the verge of the destruction caused by the Second World War, with its specter of the atomic bomb and genocide, a world that has become "uninhabitable" and has run "amok" ("Across the Board" 127). What is interesting is that Saroyan decides to include a rant directed against Thomas Pinkerton, the capitalist from Wall Street. It is Pablo, the Filipino, who voices what Ramon Internationale, the protagonist of our first story, was unable to verbalize, in a series of questions that leave the rich man fumbling for an answer:

What do you know about the Philippine Islands? ... Have you studied the situation, imports and exports, sanitation, public schools, free clinics, agriculture, mining and manufacture of the Philippine Islands? ... Do you know the problems of the people of the Philippine Islands? ... Is the situation of the Filipino boy in America something you have put on the scale of justice? ... Do you know the cultural, racial, and religious background of the Filipino people? (124)

Kritika Kultura 35 (2020): 111-117

(C) Ateneo de Manila University

<http://journals.ateneo.edu/ojs/kk/> 
Pablo's diatribe against the neocolonial marginality of which the Filipinos are victims expresses what Ramon's litany “you know nothing” never explicitly stated. He is courageous to challenge "the misrepresentation" of their identity in the host country: Filipinos "take pride in their kinship with America," they "come to America. They are American citizens" (126). Furthermore, it is Pablo who makes the symbolic birth of the baby a success, thereby arousing a hope for the continuity of the miracle of life despite the maelstrom of history and the loss of faith in a world "inhabited by the dead, not the living" (133). Piper cannot help expressing his amazement at Pablo's ability to cope with the emergency "with perfect timing, magnificent calm, considerable humor, perfect English, and not the slightest abandonment of his own ego" (239). Despite the agony of the war and the imminent menace of destruction, it is still possible to bet, as the puzzling title indicates, on a near future. And Filipinos have, obviously, a say in the construction of this tomorrow.

\section{CONCLUSIONS}

Filipinos occupy a small yet significant space in Saroyan's oeuvre. Unlike the rest of the ethnic minorities that appear in his fiction, Filipinos are able to carve out a niche where they resist the oppression and counteract the silence by opposing the hegemonic strategies of invisibility, silence and lack of agency. Ramon Internationale's refusal to be defeated in the framed match and his ability to mobilize the police and halt the city's daily life, thereby becoming its new gravitational center, marks a victory at least in the imaginary world of an auditorium named Dreamland. His laconic response "You know nothing" with which he rounds off the bout in the ring encapsulates the history of forced displacement and neocolonial exploitation of deracinated manongs in the United States. Although Saroyan draws on a hodgepodge of racial stereotypes ranging from the story's title, the depiction of Ramon as a giant-sized baboon, to the use of narratorial techniques of the tall tale tradition, the yarn-spinning community's deep cultural matrix is disavowed: the reader, much like the audience of the match, sides with the Filipino against the prevailing ideologies of their racial inferiority.

Similarly, Vernon Roxas's ability to resurrect the discarded junk and infuse the jalopy with a new life gives a new hope to the pastoral ideal of America. Despite the collapse of the economy, he still makes it possible to reconcile the machine with the garden. The team of Filipinos demonstrates, through their spirit of cooperation and challenge of imposed social rules (Cadillacs are not for workers, immigrants must not appropriate middle-class dress codes) that America is still the boundless space of freedom where it is still possible to resist assimilation and cultural oneness. 
That Filipinos can renovate, through their defiance of norms and non-conformity, the belief in the power of individuals to trust themselves and overcome hindrances is revalidated, once again, by Pablo, the Filipino kitchen boy of the play "Across the Board on Tomorrow Morning." Pablo's tirade against the capitalist's abuses unravels what Ramon's complaint was not able to spell out. His cooperation in the baby's birth nurtures the hope that, in Adamic's words, "the promise" of America as "a body of idealism" where "all citizens, whatever their national or racial origins" become "equal partners"(62) can, and must, be fulfilled.

Kritika Kultura 35 (2020): 113-117

(c) Ateneo de Manila University

<http://journals.ateneo.edu/ojs/kk/> 


\section{Notes}

1. Saroyan invariably uses the words race or racial and tribe. It is not until 1941 when the word "ethnicity," an obsolete term since the eighteenth century, is employed again by sociologist W. Lloyd Warner (Sollors xiii).

2. At a time when he was struggling to find a voice that could express and celebrate his Irish identity, Sean O'Faolain found an ideal source of inspiration in Saroyan's stories about Armenians.

3. In "The Boys in the Back Room" (1941), Edmund Wilson endorses the opinion that the real problem with Saroyan is that he sometimes reads as a columnist, the kind "who depends entirely on a popular personality, the kind that never reads, who does not know anything in particular about anything" (29).

4. Written in 1935 and included in the 1938 volume Love, Here is my Hat, the well-known story inspired Uzbek director Abbasov Shuhrat's 1958 diploma film. It is at this point advisable to remember that John Fante's stories about Filipinos living in California, namely "Helen, Thy Beauty is to Me" and "The Dreamer," were brought out in 1942 and 1947 respectively, making their appearances years after Saroyan's pieces, published during the 1930s. Clara Weathermax's proletarian novel Marching! Marching! (1935), which Carlos Bulosan mentions in his autobiography as one the earliest texts of US literature dealing with Filipinos as flesh-and-blood characters, is contemporary with the publication of Saroyan's "The Filipino and the Drunkard." Filipinos are also present in Saroyan's theater. Pedro the Filipino dressed in a "thirty-five dollar suit, made to order," smoking "Bobby Burns panatelas" and playing snooker with a Greek is one of the characters briefly mentioned by Harry the comedian in a monologue that provides a grim view of life marked by hunger, war, and the ominous presence of Hitler ("The Time of Your Life" 94-95). "Across the Board on Tomorrow Morning" (1942) is his first play including a pair of Filipinos as dramatis personae.

5. Fresno's establishment called the Armenians "Fresno niggers" and used all kinds of segregation measures against them (Bobelian 110).

6. Carlos Bulosan expresses an identical concern for the recovery of the ideal of America as the land of "freedom for all regardless of color, station and beliefs" (188) when Allos reproduces his brother Macario's progressive ideas about the Filipinos in California: "America is also the nameless foreigner, the homeless refugee, the hungry boy begging for a job and the black boy dangling on a tree" (189).

7. Interestingly enough, Cadillacs and other GM brands were not sold to blacks in 1933 as part of the car manufacturer discriminatory policy. The sales of cadillacs, considered as luxury cars, went down dramatically during the Great Depression. As John E. Silvia notes, the company changed this policy when it was discovered that white people were paid to buy Cadillacs for African Americans so they eventually decided to open the market for this minority (111). 


\section{Works Cited}

Adamic, Louis. "This Crisis is an Opportunity." Common Ground, vol. 1, no. 1, 1940, pp. 62-73.

Balakian, Nona. The World of William Saroyan. Bucknell UP, 1998.

Bhabha, Homi K. The Location of Culture. Routledge, 1994.

Bobelian, Michael. Children of Armenia: A Forgotten Genocide and the Century-Long Struggle for Justice. Simon \& Schuster, 2009.

Boelhower, William. Through a Glass Darkly: Ethnic Semiosis in American Literature. Oxford UP, 1987.

--. "Ethnic Trilogies: A Genealogical and Generational Poetics." The Invention of Ethnicity, edited by Werner Sollors, Oxford UP, 1989, pp. 158-75.

Briones, Matthew M. Jim and Jap Crow: A Cultural History of the 194os Interracial America. Princeton UP, 2012.

Brown, Carolyn, S. The Tall Tale in American Folklore and Literature. U of Tennessee P, 1987.

Bulosan, Carlos. America is in the Heart: A Personal History. Introduced by Carey McWilliams, U of Washington P, 2002.

Burr, Eugene. "Saroyan's 'Across the Board': A Cross to Bored Customers." The Billboard, 4 Apr. 1942, p. 10.

-.. "New Play on Broadway": Review of "Across the Board on Tomorrow Morning". The Billboard, 29 Aug. 1942, p. 10.

Calonne, David Stephen. William Saroyan: My Real Work is Being. U of North Carolina P, 1983.

Campomanes, Oscar. “The New Empire's Forgetful and Forgotten Citizens: Unrepresentability and Unassimilability in Filipino-American Postcolonialities." Critical Mass: A Journal of Asian American Cultural Criticism, vol. 2, no. 2, 1995, pp. 145-200.

--. "Filipinos in the United States and their Literature of Exile." Reading the Literatures of Asian America, edited by Shirley Geok-lin Lim and Amy Ling, Temple UP, 1992, pp. 49-78.

Denning, Michael. The Cultural Front: The Laboring of American Culture in the Twentieth Century. Verso, 1996.

España-Maram, Linda. Creating Masculinity in Los Angeles' Little Manila: Working-Class Filipinos and Popular Culture, 1920s-1950s. Columbia UP, 2006.

Fante, John. "Bill Saroyan." Common Ground, vol. 1, no. 2, 1941, pp. 64-66.

--. The Wine of Youth, Selected Stories. HarperCollins, 2010.

Franks, Joel S. Crossing Sidelines, Crossing Cultures: Sport and Asian Pacific American Cultural Citizenship. UP of America, 2010.

Foster, Edward Halsey. William Saroyan: A Study of the Short Fiction. Twayne Publishers, 1991.

Goldberg, David Theo. The Racial State. Blackwell, 2002.

Kritika Kultura 35 (2020): 115-117

(C) Ateneo de Manila University

<http://journals.ateneo.edu/ojs/kk/> 
Haslam, Gerald. "William Saroyan and San Francisco." San Francisco in Fiction: Essays in a Regional Literature, edited by David Fine and Paul Shenazy, U of New Mexico P, 1995, pp. 111-124.

Lee, Erika and Judy Yung. Angel Island: Immigrant Gateway to America. Oxford UP, 2010.

Le Espiritu, Yen. Home Bound: Filipino American Lives Across Cultures, Communities, and Countries. U of California P, 2003.

Lye, Colleen. America's Asian Racial Forms and American Literature, 1893-1945. Princeton UP, 2004.

Marx, Leo. The Machine in the Garden: Technology and the Pastoral Ideal in America. 1964. Oxford UP, 2004.

Matsumoto, Valerie J. City Girls: The Nisei Social World in Los Angeles, 1920-1950. Oxford UP, 2014.

Mellow, James R. Walker Evans. Basic Books, 2001.

Nathan, George Jean. The Theatre Book of the Year 1942-1943: A Record and an Interpretation. Farleigh Dickinson UP, 1971.

Rahv, Philip. "Narcissus," Review of The Daring Young Man on The Flying Trapeze. Partisan Review, vol. 2, 1935, pp. 84-85.

Sammons, Jeffrey T. Beyond the Ring: The Role of Boxing in American Society. U of Illinois P, 1990.

San Juan, Epifanio, Jr.. History and Form: Selected Essays. Ateneo de Manila UP, 1996.

--.."Internationalizing the US Ethnic Canon: Revisiting Carlos Bulosan." Comparative American Studies, vol. 6, no. 2, 2008, pp. 123-143.

--. "History, Class-Consciousness, Imperialism: Re-Visiting Carlos Bulosan's America is in the Heart." Cultural Logic: Marxist Theory \& Practice, vol. 23, 2019, pp. 1-15.

Saroyan, William. Inhale and Exhale. Books for Libraries P, 1972.

-.. "Introduction." Three Worlds 1934-1939. Hairenik P, 1939, pp. xi-xvii.

-.. "The Time of Your Life." Three Plays. Harcourt, Brace and Company, 1940, pp.13-2oo.

--. Peace, It's Wonderful. Modern Age Books, 1939.

-.. "Across the Board on Tomorrow Morning." The Beautiful People and Other Plays, Faber and Faber, 1943, pp.107-139.

-.. Short Drive, Sweet Chariot. Phaedra, 1966.

--. My Name is Saroyan: A Collection, edited by James H. Tashjian, Harcourt Brace Jovanovich, 1983.

-.. "Haratch." 1979. An Armenian Trilogy, edited by Dickran Kouymjian, The P at California State U, 1986, pp. 123-179.

-.. The William Saroyan Collection at Stanford. Stanford U, 1997.

Silvia, John, E. Dynamic Economic Decision Making: Strategies for Financial Risk, Capital Markets, and Monetary Policy. Wiley, 2011.

Sollors, Werner. "Introduction." The Invention of Ethnicity, edited by Werner Sollors. Oxford UP, 1989, pp.ix-xx.

Streible, Dan. Fight Pictures: A History of Boxing and Early Cinema. U of California P, 2008. 
Vials, Chris. Realism for the Masses: Aesthetics, Popular Front Realism and U.S. Culture 1935-1947. U of Mississippi P, 2009.

Weathermax, Clara. Marching! Marching! The John Day Company, 1935.

Wilson, Edmund. "The Boys in the Back Room." Classics and Commercials: A Literary

Chronicle of the Forties, Random House, 1950, pp. 19-56.

Wolf, Eric. Europe and the People without History. U of California P, 1982.

Wonham, Henry B. Mark Twain and the Art of the Tall Tale. Oxford UP, 1993.

Kritika Kultura 35 (2020): 117-117

(c) Ateneo de Manila University 